<原 著 $>$

\title{
慢性肝炎の経過中に出現する亜広範性肝壊死に 関する臨床病理学的検討
}

\section{恩地 森一 堀池 典生 広田 俊子 太田 康幸*}

\begin{abstract}
要 旨：慢性肝炎の経過中に，劇症肝炎に相当する肝不全症状が出現し，1回の急性增悪で， 旰硬変纪進展する症例の存在を証明した。急性堌悪の程度は，T. bilirubin $8.3 か 550.5 \mathrm{mg} / \mathrm{d} l$ で, 平均 $26.7 \pm 16.3 \mathrm{mg} / \mathrm{d} l, \mathrm{GOT} 1,053 \pm 943 \mathrm{IU} / l$, ヘパプラスチンテスト $10 \%$ から $23 \%$ て平均 $16 \pm 4.7 \%$ であった，治療としては血浖交换療法を 5 例中 3 例で施行した。急性增悪前, 中で, 全例 IgM 型 HA 抗体陰性で, B 型肝炎の 3 例全例で, HBe 抗体陽性にもかかからず, DNA-p の上昇を認め, $\delta$ 抗体は陰性であった。急性増悪後の腹腔鏡, 肝生検では全例に亚広範性肝罗死 を認め, 5 例中 4 例で，肝予備能が極度に低下した壊死後性肝硬変に進展していた。 また急性 増悪後半年以上の経過镜察をした 3 例中 2 例に，食道静脈瘤の出現を認めた。
\end{abstract}

\section{卖引用語： 慢性肝炎 重広範性肝壊死 肝硬変}

\section{緒 言}

広範性ないし亜広範性肝壊死は, 通常, 劇症肝炎之 亜急性肝炎にみられ，その病理組織学的研究も多い。 一方, 慢性肝炎に扔ける肝細胞壊死には, 病理組織学 的 $K$, focal necrosis ( $F N)$, piecemeal necrosis (PMN), sublobular necrosis（SN）があるとされて いる. 慢性肝炎が肝硬変に進展するには SN が重要で ある. 最近, 著者らは, 慢性肝炎の自然経過中に, 劇 症肝炎に相当する急性肝不全が出現する重篤な増悪が 出現し, その回復後, 壊死後性肝硬变に進展し, 肝生 検組織で覀広範性壊死を認める症例を経験した。これ らの症例とSNを臨床病理学的に検討し, 慢性肝炎に おける肝細胞壊死に批いてす, 亜広範性肝壊死が存在 することを証明したので，その概要を報告する．

\section{対象と方法}

対象は, 重篤な増覀の前後に腹腔鏡検查々病理組織 学的検討をし得た, 慢性活動性肝炎 (以下 CAH) 4 例 で， B 型と非 B 型のそれぞれ 2 例と，初期肝硬変 1 例 の計 5 例である. 非 B 型 CAH の 2 例は，ステロイド ホルモン中止後に增悪が出現したが， B 型 $\mathrm{CAH} の 2$ 例は特殊治療を行っていない. 対照として, (1) SN の 増悪であることを肝生検により確認した CAH 7 例 と, (2) 通常の CAH の経過で, 肝硬変 (LC) に進展

\footnotetext{
*愛媛大学第 3 内科
}

$<$ 受付日62年 1 月 9 日 $>$
した 7 例を検討した。血中の $\mathrm{HBe}$ 抗原抗体と $\delta$ 抗体 は，ダイナボット社製キットを用いて RIA 法で測定し た.また, HBV-DNA polymerase (DNA-p)は Kaplan の変法を用いて測定した。 なお DNA-p の正常値は200 $\mathrm{cpm} /$ 血清 $500 \mu l$ 末満である. 統計学的処理は $\mathrm{t}$ 検定を 用いた。

\section{成 績}

対象症例 5 例の增悪期の肝機能検査と治療を Table 1 に示した。 また, SN の増悪であることを増悪の前後 で組織学的に確認し得た CAH 7 例と比較した成績を 示した. IgM 型の A 型肝炎ウイルス抗体は全例陰性で あった. HBs 抗原陽性の 3 例は, 全例 $\mathrm{HBe}$ 抗体陽性, $\delta$ 抗体陰性であった。意識障害は, 死亡した 1 例を除い て軽度で， 5 例中 3 例で犬山シンポジゥムの肝性昏睡 度 Iであった，腹水は全例に認めた．総ビリルビン值 は, $8.3 \mathrm{mg} / \mathrm{d} l$ から $50.0 \mathrm{mg} / \mathrm{d} l$ で, 平均 $26.7 \pm 18.3 て ゙$, $\mathrm{SN}$ のそれに比べて有意に高值であった $(\mathbf{p}<0.005)$. ヘパプラスチンテストは, $10 \%$ から $23 \%$ で, 平均 $16 \pm$

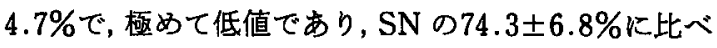
て有意に低值であった $(p<0.005)$. DNA-p は2,567士 $2,267 \mathrm{cpm}$ で, SN に比べ, 差を認めなかった. 主な治 療としては, 全例でステロイドホルモンの投与を行い, 3 例で血椋交換を行った。

症例 1 今○秀O，42歳，男性. 輸血歴及び领酒歴 なし. 現病歴：昭和57年 1 月頃, 心窝部不快感出現し て, 近医で B 型慢性肝炎と診断され，2 力月間入院治 
Table 1 Summary of patients profile.

\begin{tabular}{|c|c|c|c|c|c|c|c|c|c|c|c|c|c|}
\hline \multirow[b]{2}{*}{ Case } & \multirow[b]{2}{*}{ Sex } & \multirow[b]{2}{*}{ Age } & \multirow[b]{2}{*}{ Etiology } & \multirow[b]{2}{*}{ D.C. } & \multirow[b]{2}{*}{ Ascites } & \multicolumn{5}{|c|}{ LFT } & \multirow{2}{*}{$\begin{array}{l}\text { DNA-P } \\
\text { (cpm) }\end{array}$} & \multirow{2}{*}{$\begin{array}{l}\text { Duration } \\
\text { (month) }\end{array}$} & \multirow[b]{2}{*}{ Therapy } \\
\hline & & & & & & $\underset{(\mathrm{mg} / \mathrm{d} l)}{\mathrm{T} . \mathrm{Bil}}$ & $\underset{(\mathrm{GOT} / l)}{\mathrm{GOT}}$ & $(\mathrm{GPT} / l)$ & $\underset{(\%)}{\mathrm{HPT}}$ & $\mathrm{PT}$ & & & \\
\hline 1 & Male & 42 & $\begin{array}{l}\text { B, Anti- } \delta(-) \\
\text { Anti-HBe(+) }\end{array}$ & I & + & 39.5 & 1371 & 1440 & 17 & $\stackrel{28}{\%}$ & 5019 & 8 & $\begin{array}{l}\text { Plasma exchange } \\
\text { PSL }\end{array}$ \\
\hline 2 & Male & 35 & $\begin{array}{l}\text { B, Anti- } \delta(-) \\
\text { Anti-HBe(+) }\end{array}$ & I & + & 50.5 & 237 & 404 & 14 & $\begin{array}{l}17.3 \\
(\mathrm{sec})\end{array}$ & 544 & 4 & Plasma exchange \\
\hline 3 & Female & 52 & $\begin{array}{l}\text { B, Anti- } \delta(-) \\
\text { Anti-HBe(+) }\end{array}$ & I & + & 8.3 & 2560 & 1660 & 10 & $\begin{array}{l}19.4 \\
(\mathrm{sec})\end{array}$ & 2140 & 5 & Fresh frozen plasma \\
\hline 4 & Female & 38 & NANB & - & + & 10.3 & 619 & 619 & 23 & $(\%)$ & & 8 & $\begin{array}{l}\text { PSL } \\
\text { Azathiopurine }\end{array}$ \\
\hline 5 & Female & 43 & NANB & IV & + & 25.0 & 478 & 378 & 16 & & & 6 & $\begin{array}{l}\text { Plasma exchange } \\
\text { PSL }\end{array}$ \\
\hline \multicolumn{4}{|c|}{ Total } & \multicolumn{2}{|c|}{5 cases } & $\begin{array}{l}26.7 \\
\pm 18.3\end{array}$ & $\left.\begin{array}{l}1053 \\
\pm 943\end{array}\right]$ & $\begin{array}{l}900 \\
\pm 606\end{array}$ & \multicolumn{2}{|c|}{$\left.\begin{array}{l}16 \\
\pm 4.7\end{array}\right] .}$. & $\begin{array}{l}2567 \\
\pm 2267\end{array}$ & & \\
\hline \multicolumn{4}{|c|}{$\begin{array}{l}\text { Exacerbation in CAH } \\
\text { with sublobular necrosis }\end{array}$} & \multicolumn{2}{|c|}{7 cases } & $\begin{array}{l}0.9 \\
\pm 0.2\end{array}$ & $\begin{array}{l}311] \\
\pm 147\end{array}$ & $\begin{array}{l}636 \\
\pm 221\end{array}$ & \multicolumn{2}{|c|}{$\begin{array}{l}74.3 \\
\pm 6.8\end{array}$} & $\begin{array}{l}3714 \\
\pm 2958\end{array}$ & & \\
\hline
\end{tabular}

D.C. : Disturbance of consciousness (classification of Inuyama symposium)

LFT : Liver function test during exacerbation stage PSL : Predonisolone

Duration : Duration of abnormal liver function test

$*$ : $<0.01 * *:<0.005 * * * p<0.005$

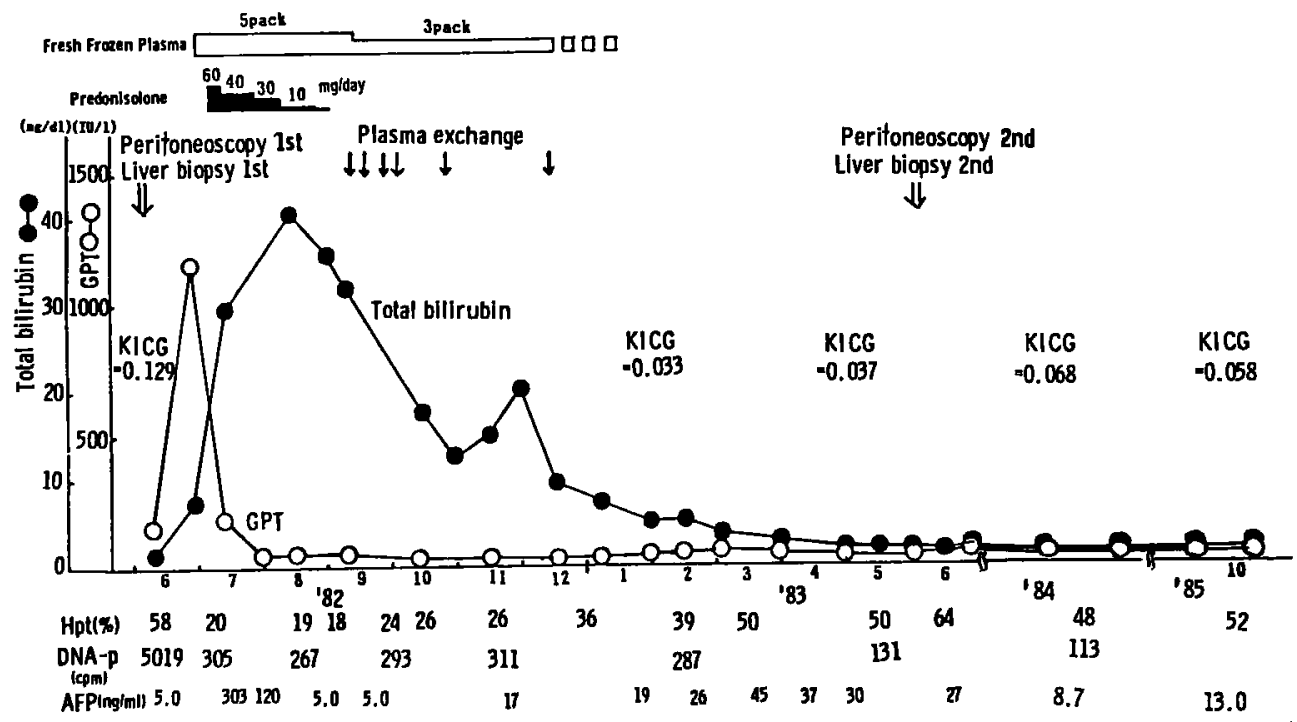

Fig. 1 Clinical course of Case 1

療. 同年 4 月，当科受診し，6月 7 日入院。入院時， 黄疸・觬血なく，肝・脾触知せず，腹水なし，入院時 検查成績では, T. bilirubin $1.3 \mathrm{mg} / \mathrm{d} l$, GOT $66 \mathrm{IU} / l$, GPT 166IU/l, AIP 137IU/l, ChE 83ChEU, ZTT 19 $\mathrm{U}$, TTT 12U, HBs Ag 陽性 $\left(>2^{12}\right)$, anti-HBs $(-)$, anti-HBc は200倍希釈血清でも inhibition\%は96\% と 高力価陽性であった. $\mathrm{HBeAg}$ 陰性 (0.3), anti-HBe 陽性 (>100\%)，入院後の経過を Fig. 1 に示した，腹
腔鏡・肝生検検査後 1 週間の時点で, GPT $1,371 \mathrm{IU} / l$ まで上昇，さらに総ビリルビン值が次第に上昇し，39.5 $\mathrm{mg} / \mathrm{d} l$ K達した。 ヘパプラスチンテストは $18 \%$ まで低 下したため, 血浆交換療法も6 回施行. その後, 稳ビ リルビンは徐々に低下したが，正常化するには約14カ 月を要した， $\mathrm{HBe}$ 抗原陰性, $\mathrm{HBe}$ 抗体陽性であった が，DNA-p は5,019cpmに上昇し，増悪がおさまると ともに陰性化した. $\mathrm{K}_{\mathrm{ICG}}$ は，増悪前に0.129であったも 


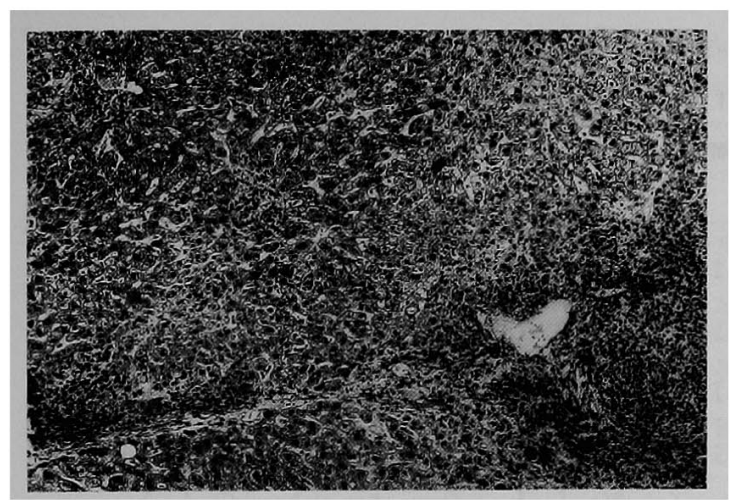

Fig. 2 Liver histology in case 1 before the exacerbation of submassive necrosis. A portal tract is enlarged because of fibrosis, and is infiltrated with mononuclear cells and its margin is irregular. There is a bridging necrosis (portal and portal tract). Chronic active hepatitis ( $\mathrm{HE}, \times 95)$

のが, 0.033 ま゙低下し,増悪から 3 年後は0.047であっ た. 増悪前は認めなかった食道静脈瘤は，増悪出現後 1 年10力月に著明な red-color signを伴った静脈瘤を 認め, 3 年後には硬化療法を施行した。腹部 CT では, 増悪後, 肝は高度に萎縮し, 著明な脾腫を諗めた。

増悪の前後に腹腔鏡検査を行った，初回腹腔鏡検查 （昭和57年 6 月 15 日）．脾畽は極く軽度．肝紋理は軽度 増強. 大白色肝で, 島田分類の200番地であった. 第 2 回腹腔鏡検査 (昭和58年 5 月 31 日), 脾は中等度腫大. 肝は初回に比へ，高度に萎縮し，小さな浅い陌凹がび まん性に認められた。少半球状結節が少数散見され， 多数のリンハ小水泡と傍㑪静脈の怒張及び腹水の眝留 を認めた。

増悪前後の肝生検組織像を, Fig. 2, 3 に示した. 増 悪前では,リンパ球浸潤と線維増生により，門脈域は 払大し，一部では門脈一門脈結合を認めたが，中心静 脈一門脈結合は認めなかった。一部リンパ滤胞を認め た.

増悪後の組織像は，一部再生結節を認め, 1/2小葉大 ないしは 1 小葉大の肝細胞壊死を認め, 線維に团まれ たロゼット形成肝細胞を多数認めた。壊死後性肝硬変 と診断された。䀒組織内 $\mathrm{HBs}$ 抗原及び HBc 抗原の局 在に関しては, HBs 抗原は増悪前は膜状に肝細胞に表 出していたが，増悪後は消失し， $\mathrm{HBc}$ 抗原は，増悪前 は核及び細胞質に多数恋めたが，増悪後には消失して いた.

症例 2 渡 $\bigcirc$ 金 $\bigcirc, 35$ 歳, 男性. 輸血麼及び领酒歴

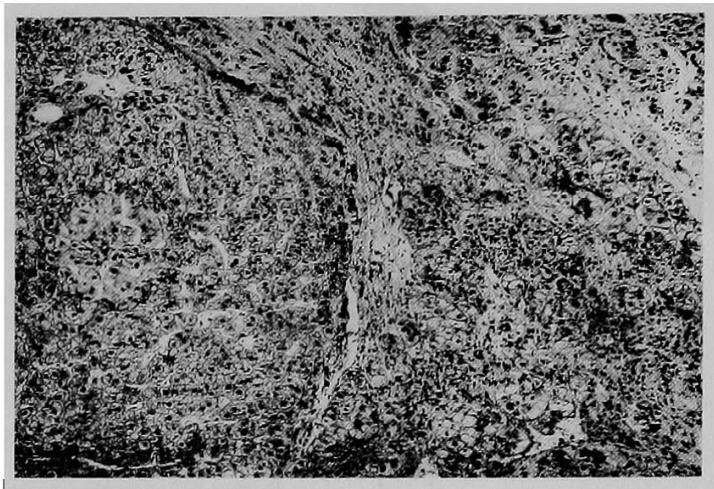

Fig. 3 Liver histology seen in case 1 after the exacerbation. There is a nodular formation and submassive necrosis, which consists of fibrosis and rosettes formed by swollen pale-staining liver cells. Postnecrotic liver cirrhosis $(\mathrm{HE}, \times 95)$

なし. 現病歴：昭和58年 12 月, 献血の際, HBs 抗原陽 性を指摘される。 anti-HBc は200倍希釈血清でも inhibition\%は98\%と高力価陽性であった，HBe 抗原陽性 であったが，肝機能検査は正常. 昭和59年 4 月，全身 倦急感出現, GOT $840 \mathrm{IU} / l$, GPT $1,074 \mathrm{IU} / l$ で入院. 一般肝庇護療法で, 肝機能検査改善し, 昭和59年 5 月 25日, 初回腹腔鏡検査施行. $\mathrm{HBe}$ 抗原消失し, $\mathrm{HBe}$ 抗 体陽性化，肝機能検查も正常化した，昭和59年12月初 旬上り，澏気，食欲不振出現。昭和 60 年 1 月 4 日，眼 球結膜黄染し，入院. 入院時現症では，眼球結膜黄染， 肝は一横指径触知し，王痛あり．腹水を認める，入院 時検查では, T. bilirubin $2.9 \mathrm{mg} / \mathrm{d} l$, GOT $237 \mathrm{IU} / l$, GPT $404 \mathrm{IU} / l$, AlP $185 \mathrm{IU} / l$, ChE 346ChEU, ZTT $9 \mathrm{U}$, TTT $3.8 \mathrm{U}$, Cholesterol $149 \mathrm{mg} / \mathrm{d} l, \mathrm{HBs} \mathrm{Ag}$ 陽 性, anti-HBs 陽性 (RIA 法), HBeAg 陽性 (4.8), anti-HBe士 (33.8\%). 入院後の経過を Fig. 4 に示し た. 初回の腹腔鏡検査後, 5 カ月して GPT は上昇, 最 高404IU $/ l$ まで達し, その後急速に改善した. 総ビリル ビンは, $50.5 \mathrm{mg} / \mathrm{d} l$ まで上昇した. ヘパプラスチンテ ストは最低14\%まで低下したが，次第に上昇し，増覀 出現後10カ月後には，58\%にまで回復した，血浆交換 を 3 回施行後, ビリルビン值は次第に低下し，増悪出 現後 6 カ月で正常化した. 初回腹腔鏡検查時陰性化し ていた $\mathrm{HBe}$ 抗原は，増悪時に陽性化したが， $\mathrm{HBe}$ 抗 体は一時陰性化したが, その後は陽性のままであった。 HBV DNA-p は543.5cpm と上昇した。 $K_{\text {ICG }}$ は0.161で あったが，増悪後0.082まで低下した。腹部 CTは，増 


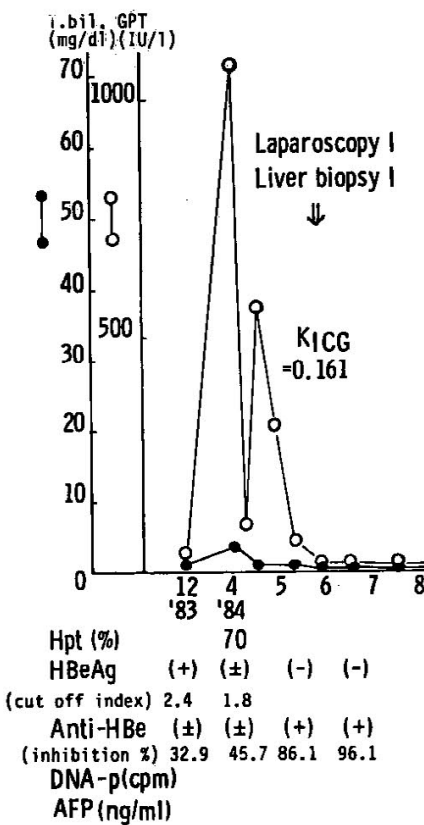

$$
\begin{aligned}
& \text { FFP H|llil III } \\
& \text { G-I therapy 貣圈 }
\end{aligned}
$$

Predonisolone

Plasma exchange Laparoscopy II

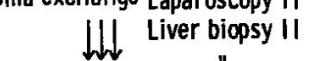

Fig. 4 Clinical course of Case 2

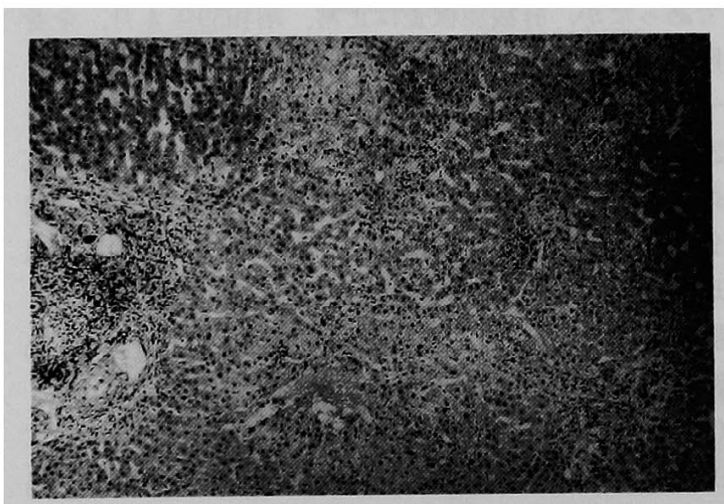

Fig. 5 Liver histology seen in case 2 before the exacerbation of submassive necrosis. Focal and piecemeal necrosis and portal fibrosis are seen. There is no bridging necrosis. Chronic active hepatitis (HE, $\times 95)$

悪期に肝は萎縮し，脾は腫大していた．初回腹腔鏡検 查(昭和59年 5 月 25 日), 脾腫大なし。肝は腫大し, 肝 紋理は軽度増強。大白色肝で, 島田分類の 200 番地で あった．第 2 回腹腔鏡検查(昭和60年 5 月 17 日)，中等 度の脾腫を認め，肝はびまん性に萎縮し，少数の小半 球状結節を散在性に認めた。ICG を静注すると，直径 0.5 1.0mm の大きさの小結節が観察された. 増覀前

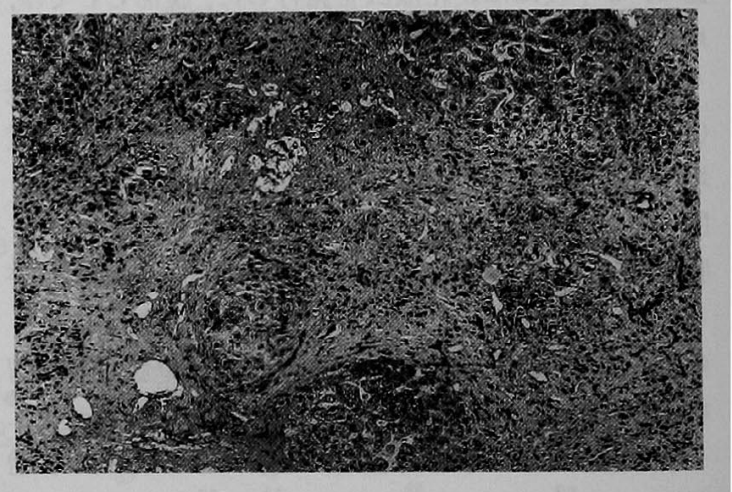

Fig. 6 Liver histology seen in case 2 after the exacerbation. There are nodular formation and submassive necrosis which consists of fibrosis and rosette formation of liver cells. Postnecrotic liver cirrhosis (HE, $\times 95$ )

後の肝生検組織の写真を Fig. 5, 6 亿示した。増悪前の 生検組織では，門脈域はリンパ球を主体とした円形細 胞浸潤之線維增生により抬大していた。限界板は破罗 され，巣状髙死も多数認めたが, bridging necrosisは 認めなかった．慢性活動性肝炎の所見であった．増悪 後の生検組織では, 1/2 1 小葉大の線維化部分および ロゼット形成肝細胞部分を認め, submassive necrosis 
Table 2 Peritoneoscopic and histopathologic findings observed before and after submassive hepatic necrosis in patients with chronic active hepatits.

\begin{tabular}{|c|c|c|c|c|c|c|c|}
\hline \multirow{2}{*}{ Case } & \multirow{2}{*}{$\begin{array}{l}\text { Interval } \\
\text { (month) }\end{array}$} & \multicolumn{2}{|c|}{$\mathrm{K}_{\mathrm{ICG}}$} & \multicolumn{2}{|c|}{ Peritoneoscopic findings } & \multicolumn{2}{|c|}{ Histopathological findings } \\
\hline & & $\mathrm{b}$ & a & b & a & b & a \\
\hline 1 & 11.5 & 0.129 & 0.037 & $\begin{array}{l}\text { EWL } \\
\text { 【200】 }\end{array}$ & NL, atrophic & $\begin{array}{l}\mathrm{CAH} \\
\text { [II Af(d)] }\end{array}$ & $\begin{array}{l}\text { LC with submassive } \\
\text { necrosis }\end{array}$ \\
\hline 2 & 12 & 0.161 & 0.082 & EWL & $\begin{array}{l}\text { NL, atrophic } \\
\llbracket 318,2 \mathrm{e} \rrbracket\end{array}$ & $\begin{array}{l}\mathrm{CAH} \\
\text { [II Ae] }\end{array}$ & $\begin{array}{l}\text { LC with submassive } \\
\text { necrosis }\end{array}$ \\
\hline 3 & 8 & 0.107 & 0.091 & $\begin{array}{l}\text { Early NL } \\
\text { 【312(8)】 }\end{array}$ & $\begin{array}{l}\text { NL, atrophic } \\
\text { 【318, 2e】 }\end{array}$ & $\begin{array}{l}\text { Early LC } \\
\text { posthepatitic }\end{array}$ & $\begin{array}{l}\text { LC with submassive } \\
\text { necrosis }\end{array}$ \\
\hline 4 & 13 & 0.175 & 0.069 & $\begin{array}{l}\text { EWL } \\
\text { 【206】 }\end{array}$ & $\begin{array}{l}\text { EWL } \\
\text { 【312e, 4】 }\end{array}$ & $\begin{array}{l}\mathrm{CAH} \\
\text { [II Ae] }\end{array}$ & $\begin{array}{l}\text { CAH, scar formation } \\
\text { [II Ae] }\end{array}$ \\
\hline
\end{tabular}

【 \Shimada's code number, [ ] Ohta's classification of chronic hepatitis Interval : Interval between peritoneoscopic examination
EWL: Enlarged white liver
$\mathrm{b}$ : before the examination

NL: Nodular liver

a : after the examination

Table 3 Peritoneoscopic and histopathological findings in cases transited of chronic hepatits to liver cirrhosis.

\begin{tabular}{|c|c|c|c|c|c|c|c|c|}
\hline \multirow{2}{*}{ Case } & \multirow{2}{*}{$\begin{array}{l}\text { Interval } \\
\text { (month) }\end{array}$} & \multicolumn{2}{|c|}{$\mathrm{K}_{\mathrm{ICG}}$} & \multicolumn{2}{|c|}{ Peritoneoscopic findings } & \multicolumn{3}{|c|}{ Histopathological findings } \\
\hline & & b & a & b & a & b & & \\
\hline 1 & 40 & 0.150 & 0.067 & $\begin{array}{l}\mathrm{EWL} \\
【 204,6 】\end{array}$ & $\begin{array}{l}\text { PNL } \\
(424,7)\end{array}$ & $\begin{array}{l}\mathrm{CAH} \\
\text { [SN] }\end{array}$ & LC & \\
\hline 2 & 68 & - & 0.182 & $\begin{array}{l}\text { EWL } \\
【 204,5 】\end{array}$ & $\begin{array}{l}\text { PNL } \\
\text { 【327, 8】 }\end{array}$ & $\begin{array}{l}\mathrm{CAH} \\
\text { [II Ad] }\end{array}$ & SN-LC & \\
\hline 3 & 23 & 0.159 & 0.105 & $\begin{array}{l}\text { EWL } \\
\text { 【316】 }\end{array}$ & $\begin{array}{l}\text { Early NL } \\
\text { 【324, 8】 }\end{array}$ & $\begin{array}{l}\mathrm{CAH} \\
\text { [II Ae] }\end{array}$ & LC & \\
\hline 4 & 28 & 0.087 & 0.162 & $\begin{array}{l}\text { EWL } \\
\text { 【204, 2e】 }\end{array}$ & PNL & $\begin{array}{l}\text { CAH } \\
\text { [SN] }\end{array}$ & SN-LC & \\
\hline 5 & 19 & 0.140 & 0.065 & $\begin{array}{l}\text { EPL } \\
\lfloor 317,4 】\end{array}$ & $\begin{array}{l}\text { NL } \\
\text { 【432e】 }\end{array}$ & $\begin{array}{l}\mathrm{CAH} \\
{[\mathrm{SN}]}\end{array}$ & LC & \\
\hline 6 & 32 & 0.173 & - & $\begin{array}{l}\text { EWL } \\
\text { 【100】 }\end{array}$ & $\begin{array}{l}\text { EWL } \\
【 314,2 \mathrm{e}\rfloor\end{array}$ & $\begin{array}{l}\mathrm{CAH} \\
\text { [II Ab] }\end{array}$ & Early LC & \\
\hline 7 & 34 & 0.156 & 0.173 & $\begin{array}{l}\text { EWL } \\
\text { 【202e】 }\end{array}$ & $\begin{array}{l}\text { PNL } \\
\text { 【317, 8】 }\end{array}$ & $\begin{array}{l}\mathrm{CAH} \\
\text { [SN] }\end{array}$ & LC & \\
\hline
\end{tabular}

【 \Shimada's code number, [ ] Ohta's classification of chronic hepatitis

Interval : Interval between peritoneoscopic examination, EWL: Enlarged white liver, EPL: Enlarged patchy liver, PNL : Patchy nodular liver, NL : Nodular liver, AH : Acute hepatitis, CAH : Chronic active hepatitis, LC : Liver cirrhosis, SN : Sublobular hepatic necrosis, $b$ : before the examination, $a$ : after the examination

の所見であった。再生像を一部認め, 壊死後性肝硬変 と診断した，増熏前では HBs 抗原は肝細胞膜への表 出が認められたが，増覀後では細胞質内に HBs 抗原 を認める肝細胞が散見された， $\mathrm{HBc}$ 抗原は, 増悪前少 数認められたが，増悪後は消失していた。

対象症例の重篤な増覀前後の一般肝機能検查と腹腔 鏡肝生検組織所見を Table 2 にをるて示した。

大白色肝の 2 例と, 初期結節訮の 1 例では, 重篤な 増悪後, 肝は萎縮性, 再生像の乏しい結節肝に進展し ていた。肝生検組織では, submassive necrosis を認め
た. ステロイドホルモン中止後に重篤な増悪が出現し た非 B 型の慢性訮炎では，増悪前は肝紋理が増強し， 区域化が観察された，漏斗肝様に，溝状の宿凹るみら れた. 増悪後では,さらに再生が進み，满状陥凹はさ らに深く明瞭となっていた。肝生模組織では，慢性肝 炎の像と痗痕部分が観察された。

$\mathrm{K}_{\mathrm{ICG}}$ を重篤化の前後で比較すると, 増悪前の0.145士 0.029 であったものが, $0.070 \pm 0.029$ と著明に低下した $(\mathrm{p}<0.02)$.

次に，通常の慢性肝绅が，増悪を繰り返しながら， 
肝硬変へ進展する過程を，腹腔鏡，肝生検組織で観察 しえた 7 例の腹腔鏡，肝生検所見を Table 3 に示し た。

肝硬変への進展に要した期間は $35 \pm 16$ 月で，重篤 な増悪で肝硬变に進展する場合よりす長期であった $(\mathrm{p}<0.05)$ ．腹腔鏡では，赤色紋理（島田の 4 番地）を 7 例中 6 例に，斑紋を 7 例中 5 例に認めた。組織学的 には，SNを 7 例中 5 例に認めた。したがって，慢性肝 炎から肝硬变への進展には SN が重要であることが確 認された。

\section{考 察}

慢性肝炎 (CH) における肝細胞壊死には，従来より focal necrosis (FN), piecemeal necrosis (PMN), sublobular necrosis（SN）が報告されている。慢性肝 炎の活動性の指標としては, Popper の報告以来 PMN が重要視されている.しかし， $\mathrm{CH}$ の LCへの進展には $\mathrm{SN}$ が PMN より重要であることが，太田らやの CAH の肝生検による長期観察から確認されている.

一方，肝不全状態を呈するような肝細胞壊死である が，慢性肝炎の経過中，その増悪に際して出現するか 否かは不明であった。

今回，著者らが経験した 2 症例は，病理組織学的に 慢性活動性肝炎であることを確認して経過観察中に, 重篤な增悪が出現した。ささらに，1）B 型 $\mathrm{CH}$ の通常の 增悪と同様に，増悪に先立ち，DNA-pの上昇がみら れ，2）IgM 型 A 型肝炎ウイルス抗体陰性，3） $\delta$ 抗体 陰性，4）特殊薬剂の使用がない，5）anti-HBc は高力 価で，B 型肝炎ウイルス（HBV）が持続感染であるこ とから，ウイルス学的には，この増悪は慢性肝资の病 因である HBV の増殖により招来されたと考支て，何 ら矛盾はないと考克られる。抗 $\mathrm{HBe}$ 抗体が 3 例之も に陽性であったが，DNA-pの上昇があった点と，肝組 織内に $\mathrm{HBc}$ 抗原が存在した点から, HBV が増殖した ことは確かである。

著者らの経験した症例は， 1 回の重篤な増悪を経過 した後，再生像の乏しい，肝萎縮の強い，壊死後性肝 硬変に進展していた，腹腔鏡時には，0.5 3.0mm ま での浅く小さな陣凹がびまん性に認められ，肝生検組 織でも，半小葉大から $2-3$ 小葉大までの壊死と， bridging necrosis が観察された。増悪の際の臨床検査 成績からは，高度の黄疾とその遷延，腹水詝留，一ハ ブラスチンテストの著明な低下があるにもかかわら ず，意識障害は軽微であり，臨床像は，劇症肝炎の亜 急性型をたは亜急性肝炎に類似していた。しかし，腹
腔鏡及び肝生検組織では，亜急性肝炎及び劇症肝炎の 亜急性型によくみられる，広範な陥凹やKartoffelleber は認められなかった。

Selmair $\mathrm{H} \mathrm{ら^{21 }}$ は，自己免疫性機序に基つくくと考克 られる CAH で黄疸が遷延し，時に意識障害を伴う重 篤な増悪を繰り返し，肝硬変に進展する，chronic aggressive hepatitisよりも予後の悪い症例を chronisch-necrotisierende Hepatitis として報告して いる.著者らの症例と, Selmair らの症例との異同は明 確ではないが，著者らの症例が，1）B 型肝炎ウイルス に基ついた増悪であること，2）増悪を繰り返していな い点が異なると考兵られる。

清水ら ${ }^{33}$ は，ステロイド離脱療法により重症化した $\mathrm{HBe}$ 抗原陽性 B 型 $\mathrm{CAH}$ の症例を報告しているが, 繢 ビリルビン値の最高值も $11.6 \mathrm{mg} / \mathrm{d} l$ までで，黄病の持 続期間も 1 カ月と，著者らの症例よりも短期間である。 また bridging necrosis の程度の壊死にとどまってい る. 小森ら (4)劇症化した HBs 抗原陽性の $\mathrm{CH}$ を報告 しているが，劇症化する前にCHであることの確認が なく, HBs 抗原キ+リアからの急性発症之考えても差 しつかえない症例と思われる。，一方，西口ら 肝不全類似の症状をきたし死亡した $\mathrm{HBe}$ 抗原陽性の $\mathrm{B}$ 型 $\mathrm{CH}$ の 1 症例を報告している。この症例は，増悪 前に $\mathrm{CH}$ であることを，腹腔鏡ならびに肝生検で確認 している。しかる，増悪前に DNA-p が増加していた。 増悪直後の腹腔鏡検查では, $0.5 \sim 2.0 \mathrm{~mm}$ 大の結節が 散在し，組織所見では, multi-lobular necrosis を認め, 偽小葉の形成を確認しており，著者らの症例と酷似し ている. しかし，死亡例であるので，増瞣後の $\mathrm{CH}$ が LCへと進展したか否かは不明である.

以上の提示症例のように, B 型 $\mathrm{CAH}$ の経過中, HBV 増殖に引き続き，劇症肝炎に相当する肝不全を 呈する重篤な増覀が出現し, bridging necrosis を伴わ ない通常のCAH から， 1 回の増悪で LC に進展する 症例の存在が明らかになった。

この様な症例は，稀な症例と思われる。しかしなが ら，第12回犬山シンポジゥムで劇症肝炎生存例の肝組 織所見を検討したところ，81例中 7 例 $(8.7 \%)$ が肝硬 変と診断されていだ . 著者らの教室で，急性肝不全を 呈し，死亡した25例中 3 例（12\%）においても，すで に偽小葉の形成が確認された。したがって，急性肝不 全として報告されている症例の5ち，早期にLCに進 展した症例は，CH が重篤な増覀を経過した症例とも 考えられ，必ずしも稀な症例ではない可能性がある。 
次に，最近注目されている“acute on chronic”7,8)な る急性肝不全の一病変がある。すなわち，慢性肝疾患 にさらに別の病因が加わり，急性肝不全が出現すると されているすのである. “acute on chronic”之, 著者 らの報告した症例とは，1）领酒歴なく IgM 型 A 型肝 炎ウイルス抗体及び $\delta$ 抗体が陰性であったこと，2） 増悪前に HBV の増殖を確認していることから，異な ると考えられる。

最後に，このような症例の成因であるが，ウイルス 増殖の程度が高い症例もあるが, SN と統計学的には 有意差のない $\mathrm{HBe}$ 抗体陽性の症例であった点から， HBV 排除淮く宿主の免疫応答が旺盛であったと考 えられる点に注目したい，しかしながら，今後詳細な 検討が必要である。

\section{結論}

慢性肝炎の経過中に，劇症肝炎に相当する重篤な増 悪が出現し, 1 回の增悪で, 肝硬变に進展する症例の 存在を証明した。慢性肝炎の肝細胞壊死には, focal necrosis (FN), piecemeal necrosis (PMN), sublobular necrosis (SN) 以外飞亜広範性肝壊死も存在 することを報告した。

なお, 本論文の要旨の一部は, 第30回日本消化器内視鏡学 会総会(松江，1985年)シンポジウムIII広範肝壊死または萎 縮と再生の腹腔鏡像で発表した.

\section{文献}

1）太田康幸, 吉田智郎, 遠藤 浩, 他：慢性肝炎の犬 山分類とその補足.「第 6 回犬山シンボシ்ウム記 録」 $1975, \mathrm{p} 34-40$

2) Selmair H, Vido I, Wildhilt E, et al: Die chronisch-nekrotisierende Hepatitis. Dtsch Med Wschr 26 : 1397-1401, 1970

3）清水 勝, 足立信幸, 時田 元, 他：ステロイド離 脱療法により重症化した HBe 抗原陽性 B 型慢性 肝炎活動型の 1 例. 肝臓 $26: 921-927,1985$

4）小林英司, 富田周介, 沖本芳春, 他：DIC 合併し 劇症化した HBs 抗原陽性肝炎の 1 例。肝䯈 21 ： 602-607, 1980

5）西口修平，武田 正，田中 隆，他：急性肝不全頑 似の症状をきたし死亡した B 型慢性肝炎の 1 例。 第30回日本消化器内視鏡学会総会誨演予報集, 1985, p209

6）太田康幸, 恩地森一, 山下善正：劇症肝炎生存例の 肝生検組織所見と転㷌.「第12回犬山シンボシ்ム 記録」1981, p189-193

7) Sherlock S: Acute (Fulminant) hepatic failure. In: Diseases of the Liver and Biliary System, (6th Edition) Blackwell Scientific Publications, Oxford, 1981, p107-115

8）武藤泰敏：肝性昏睡一病態。診断基準一急性肝不 全の定義を含めて一. 肝胆脺 $8: 621-628,1984$

\section{Studies on submassive hepatic necrosis in patients with chronic active hepatitis}

\section{Morikazu ONJI, Norio HoRIKE, Toshiko HIROTA and Yasuyuki OHTA*}

As pattern of hepatic cell necrosis in patients with chronic hepatitis ( $\mathrm{CH})$, focal necrosis, piecemeal necrosis and bridging necrosis have been reported. However, little is known about submassive necrosis appeared during the course of in $\mathrm{CH}$. Four patients $(2, \mathrm{CH}$ type $\mathrm{B}, 1, \mathrm{CH}$ type non-B, early liver cirrhosis), were examined by peritoneoscopy and liver biopsy, before and after severe exacerbation (total bilirubin $26.7 \pm 18.3 \mathrm{mg} / \mathrm{dl}$, GOT $1053 \pm 943 \mathrm{IU} / \mathrm{l}$, Normo test $16 \pm 4.7 \%$ ). All cases were negative for IgM anti-hepatitis A virus antibody. And, in 3 cases with HBs antigen positive chronic liver diseases, activity of HBV-DNA polymerase increased and anti- $\delta$ antibody was negative, anti-HBe antibody was positive.

Histological study of the liver biopsy specimens taken from the liver after the exacerbation showed the presence of submassive necrosis and rosette formation of liver cells. These liver were progressed to postonecrotic liver cirrhosis. Our observations clearly demonstrate that the patients with $\mathrm{CH}$ having submassive hepatic necrosis developed atrophic liver cirrhosis, later.

* Third Department of Internal Medicine, Ehime University School of Medicine (Ehime) 